\title{
The Oil Road Site in Rusk County, Texas
}

Timothy K. Perttula

Heritage Research Center, Stephen F. Austin State University

Follow this and additional works at: https://scholarworks.sfasu.edu/ita

Part of the American Material Culture Commons, Archaeological Anthropology Commons, Environmental Studies Commons, Other American Studies Commons, Other Arts and Humanities Commons, Other History of Art, Architecture, and Archaeology Commons, and the United States History Commons

Tell us how this article helped you.

This Article is brought to you for free and open access by the Center for Regional Heritage Research at SFA ScholarWorks. It has been accepted for inclusion in Index of Texas Archaeology: Open Access Gray Literature from the Lone Star State by an authorized editor of SFA ScholarWorks. For more information, please contact cdsscholarworks@sfasu.edu. 


\section{The Oil Road Site in Rusk County, Texas \\ Creative Commons License \\ (c) $($ i) (8)}

This work is licensed under a Creative Commons Attribution-NonCommercial 4.0 International License 


\title{
The Oil Road Site in Rusk County, Texas
}

\author{
Timothy K. Perttula
}

\section{INTRODUCTION}

The Oil Road site (D-2) in Rusk County is along Tiawichi Creek in northern Rusk County in the East Texas Pineywoods (Figure 1), about 1 mile east of the small town of Monroe, Texas. Tiawichi Creek is a tributary to Cherokee Bayou, which is in turn a northeastern-flowing tributary to the Sabine River. The Early Caddo period Hudnall-Pirtle mound site (41RK4) is on the Sabine River just east of its confluence with Cherokee Bayou.

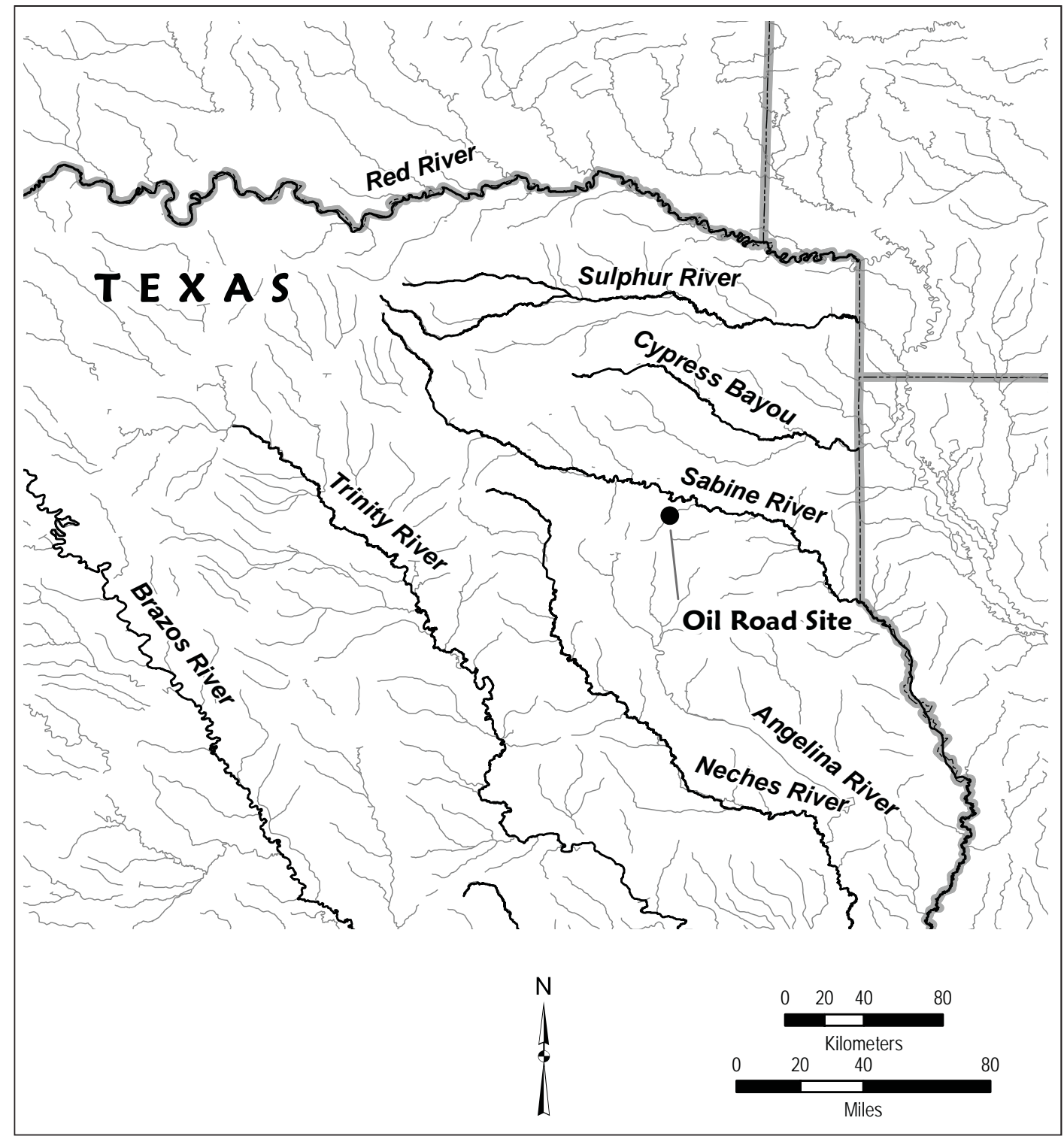

Figure 1. Location of the Oil Road site in East Texas. 
The site was located by Buddy Calvin Jones, probably in the 1950s; it has not been formally recorded or received a site trinomial. The recovered artifacts discussed in this article are probably from a surface collection obtained by Jones from the Oil Road site.

\section{Ceramic Sherd Assemblage from the Oil Road Site}

The surface collection from the Oil Road site has 104 ceramic sherds from plain, utility, and fine ware vessels (Table 1). About 88 percent of the sherds are from grog-tempered vessels, and the remainder of the vessels have been tempered with burned bone.

Table 1. Ceramic sherd assemblage from the Oil Road site.

\begin{tabular}{lccc}
\hline Ware & Grog-tempered & Bone-tempered & N \\
\hline Plain & 57 & 9 & 66 \\
Utility & 29 & 3 & 32 \\
Fine & 6 & - & 6 \\
\hline Totals & 92 & 12 & 104 \\
\hline
\end{tabular}

More than 84 percent of the 38 decorated sherds in the assemblage are from utility ware vessels, namely vessels with wet paste decorations. The remainder of the decorated sherds (15.8 percent of the assemblage) are from engraved fine ware vessels. Among the utility ware sherds from the Oil Road site, the most common decorative methods are punctated (36.8 percent of the decorated sherds) and incised (31.6 percent). Less common decorative methods in the utility wares are incised-punctated (5.3 percent), brushed (5.3 percent), appliqued-incised-punctated (2.6 percent), and brushed-incised (2.6 percent) (Table 2); a total of 7.9 percent of the decorated sherds from the Oil Road site have brushing marks.

Table 2. Decorative methods and decorative elements in the ceramic sherd assemblage from the Oil Road site.

Decorative method/

Rim Body

$\mathrm{N}$

Decorative element

Utility Ware

Appliqued-Incised-Punctated

straight appliqued ridge, fingernail punctated

rows and parallel incised lines

Brushed

overlapping brushing marks

parallel brushing marks

$\begin{array}{lll}- & 1 & 1 \\ - & 1 & 1 \\ & & \\ - & 1 & \\ & & \\ & & 2 \\ 2 & - & 2 \\ - & - & 5 \\ - & 5 & 3\end{array}$

Brushed-Incised

parallel brushing marks and incised lines

3

2

diagonal lines

horizontal lines

parallel lines

straight lines 
Table 2. Decorative methods and decorative elements in the ceramic sherd assemblage from the Oil Road site, cont.

\begin{tabular}{|c|c|c|c|}
\hline $\begin{array}{l}\text { Decorative method/ } \\
\text { Decorative element }\end{array}$ & Rim & Body & $\mathrm{N}$ \\
\hline \multicolumn{4}{|l|}{ Incised-Punctated } \\
\hline $\begin{array}{l}\text { diagonal incised triangles filled with fingernail } \\
\text { punctations }\end{array}$ & - & 1 & 1 \\
\hline parallel lines and adjacent tool punctated zone & - & 1 & 1 \\
\hline \multicolumn{4}{|l|}{ Punctated } \\
\hline fingernail punctated rows & - & 11 & 11 \\
\hline tool punctated rows & - & 3 & 3 \\
\hline \multicolumn{4}{|l|}{ Fine Ware } \\
\hline \multicolumn{4}{|l|}{ Engraved } \\
\hline curvilinear lines & - & 1 & 1 \\
\hline diagonal lines & 1 & - & 1 \\
\hline $\begin{array}{l}\text { diagonal lines and large excised triangle } \\
\text { elements* }\end{array}$ & - & 1 & 1 \\
\hline $\begin{array}{l}\text { diagonal opposed lines and large excised } \\
\text { triangle element }\end{array}$ & - & 1 & 1 \\
\hline horizontal lines & - & 1 & 1 \\
\hline parallel lines & - & 1 & 1 \\
\hline Totals & 5 & 33 & 38 \\
\hline
\end{tabular}

*bottle sherd

The appliqued-incised-punctated sherd is from the body of a jar. The sherd has a straight appliqued ridge and parallel sets of fingernail punctations and incised lines (Figure 2a). The few brushed sherds are from Bullard Brushed vessels. The incised rim and body sherds are from Davis Incised and Dunkin Incised vessels (see Suhm and Jelks 1962:Plates 18 and 19h). The one incised-punctated sherd with parallel lines and an adjacent tool punctated zone may be from a Dunkin Incised or Kiam Incised vessel (see Suhm and Jelks 1962:Plates $19 \mathrm{~g}$ and $45 \mathrm{~b}-\mathrm{c}, \mathrm{e})$. The other incised-punctated sherd - with diagonal incised triangle elements filled with fingernail punctations - compares favorably to the Canton Incised type (see Suhm and Jelks 1962:Plate 12d, h). Most of the punctated body sherds are probably from the body of Kiam Incised jars, as they usually have fingernail punctations "more or less arranged in horizontal rows" (Suhm and Jelks 1962:89).

The fine ware sherds include a rim with diagonal engraved lines oriented from left to right, a Hickory Engraved carinated bowl sherd with horizontal engraved lines (this sherd has a resinous residue on its exterior surface along with ochre staining), a body sherd with parallel engraved lines, and another body sherd (likely from a bowl) with curvilinear engraved lines; this sherd has a $1.5 \mathrm{~mm}$ diameter suspension hole.

The other two engraved sherds from the Oil Road site are from Holly Fine Engraved vessels. The first is from a carinated bowl and has diagonal opposed engraved lines on either side of a free-standing large excised triangle (see Figure 2b; see also Suhm and Jelks 1962:Plates 39e, g and 40c). The second Holly Fine Engraved sherd is from the body of a bottle. This sherd has horizontal and diagonal engraved lines with large excised pendant triangles (see Figure 2c). 


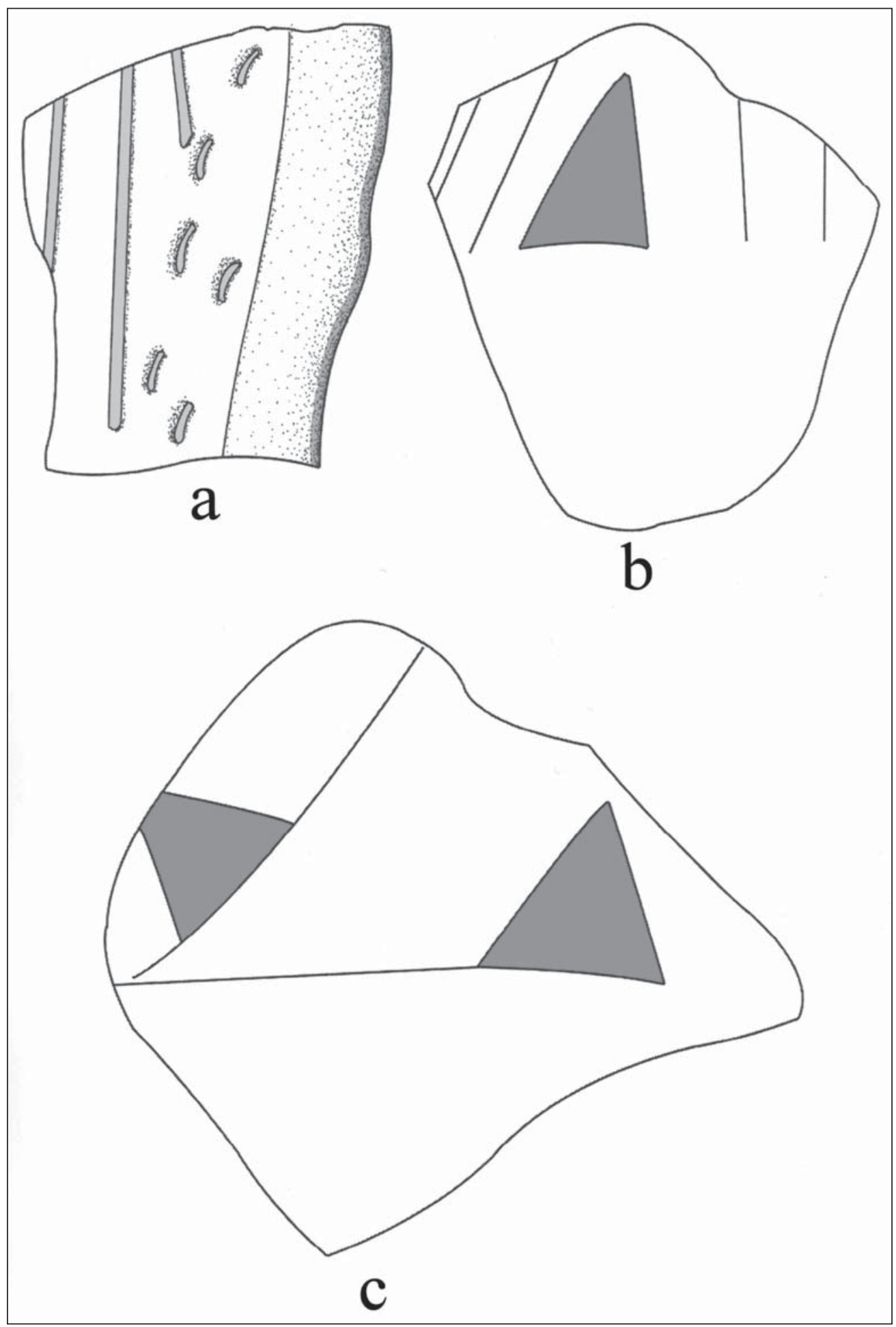

Figure 2. Selected decorative elements in the Oil Road site decorated sherds: a, appliquedincised-punctated body sherd; b, Holly Fine Engraved carinated bowl sherd; c, Holly Fine Engraved bottle sherd. 


\section{SUMMARY AND CONCLUSIONS}

The Oil Road site is an ancestral Caddo settlement on Tiawichi Creek in the mid-Sabine River basin. A collection of plain and decorated ceramic sherds collected from the site by Buddy Calvin Jones indicates that the ceramic assemblage is primarily from grog-tempered vessels, but about 12 percent are from bonetempered vessels. With the exception of the few brushed sherds in the decorated sherd assemblage (7.9 percent), which may be indicative of some use of the site after ca. A.D. 1250, the other decorated sherds are from Early Caddo period (ca. A.D. 1000-1200) vessels. These include sherds from Davis Incised, Dunkin Incised, Kiam Incised, Hickory Engraved, and Holly Fine Engraved jars, carinated bowls, and bottles. This array of ceramic types suggests that the Caddo occupation at the Oil Road site was part of the Early Caddo period community centered at the Hudnall-Pirtle site (41RK4) not far to the northeast on the Sabine River (Bruseth and Perttula 2006; Fields and Gadus 2012:636 and Figure 9.4).

\section{ACKNOWLEDGMENTS}

I thank Patti Haskins of the Gregg County Historical Museum for her assistance in the documentation of the Oil Road site collection. Lance Trask prepared the figures in this article.

\section{REFERENCES CITED}

Bruseth, J. E. and T. K. Perttula

2006 Archeological Investigations at the Hudnall-Pirtle Site (41RK4): An Early Caddo Mound Center in Northeast Texas. Caddo Archeology Journal 15:57-158.

Fields, R. C. and E. F. Gadus (editors)

2012 Archeology of the Nadaco Caddo: The View from the Pine Tree Mound Site (41HS15), Harrison County, Texas. 2 Vols. Reports of Investigations No. 164. Prewitt \& Associates, Inc., Austin.

Suhm, D. A. and E. B. Jelks (editors)

1962 Handbook of Texas Archeology: Type Descriptions. Special Publication No. 1, Texas Archeological Society, and Bulletin No. 4, Texas Memorial Museum, Austin. Reprinted in 2009, Gustav's Library, Davenport, Iowa. 